\title{
Current Status of the Operations of Clinical Microbiology Laboratories at Night, on Weekends, and during Public Holidays in Korea: Proposing a Consensus Guideline
}

Namsu Kim ${ }^{1}$, Jaehyeon Lee $^{1,2}$, Jihyun $\mathrm{Cho}^{3}$, and Hye Soo Lee ${ }^{1,2}$

${ }^{1}$ Department of Laboratory

Medicine, Chonbuk

National University

Hospital, Chonbuk

National University Medical

School; ${ }^{2}$ Research Institute

of Clinical Medicine

of Chonbuk National

University-Biomedical

Research Institute of

Chonbuk National

University Hospital, Jeonju;

${ }^{3}$ Department of Laboratory

Medicine, Wonkwang

University Hospital, Iksan,

Korea

Corresponding author:

Hye Soo Lee

Department of Laboratory

Medicine, Chonbuk National

University Hospital, Chonbuk

National University Medical

School, 20 Geonji-ro, Deokjingu, Jeonju 54907, Korea

Tel: $+82-63-250-1218$

Fax: $+82-63-250-1200$

E-mail: leehs@jbnu.ac.kr
Background: Clinical microbiological tests are conducted at night, on weekends, and during public holidays in various manners due to the fact that both manual processes and the form of working type, are not well known. Therefore, we surveyed the current running condition of these laboratories and made some suggestions for better-quality clinical microbiology tests.

Methods: We conducted a survey, both online and offline, focusing on the operating styles of clinical microbiological tests within laboratories that had participated in an external quality assessment program, conducted by the Korean Association of External Quality Assessment Service (KEQAS).

Results: Out of 341 laboratories that participated in the microbiology program of KEQAS, 128 replied to our questionnaires. In Korea, various types of operations occur within clinical microbiology laboratories. Those in night duty operate in either shifts or dedicated duties. In the case of weekend shifts, they either operated on single-day schedules (either on a Saturday or a Sunday), or over the entire weekend. For public holidays, the laboratories operated in various manners, depending on the number of days off. Among the clinical microbiological tests conducted at night, on weekends, and during public holidays, Gram staining and inoculations are the most common tasks carried out, with some laboratories conducting antibiotic susceptibility tests as well.

Conclusions: Rapid reporting of clinical microbiological test results is currently inadequate due to both cost and labor constraints, despite its many advantages. It would be ultimately beneficial for both the patient and the hospital to switch to a 24/7 operating schedule through the utilization of a variety of methods, including cost control, coordination of a fine workforce, and prioritization of tests needing to be reported.

(J Lab Med Qual Assur 2019;41:111-116)

Key Words: Laboratory management, Clinical microbiology reporting, Human resources
서론

진단검사의학과에서 실시하는 검사, 특히 임상화학이나 면
역, 혈액검사는 자동화가 잘 되어있어 야간, 주말 및 휴일에도 검사가 진행되므로 진료에 많은 도움이 되고 있다. 그러나 임 상미생물검사는 수작업으로 시행되는 검사의 비중이 높으며, 
자동화된 검사라 할지라도 검사과정의 많은 부분을 수작업으 로 시행하고 있기 때문에 국내 임상미생물검사실의 야간, 주말 및 휴일의 근무형태 및 종목은 기관에 따라 다양하다.

임상미생물검사의 빠른 검사 및 보고는 환자 진료의 질을 높 일 뿐만 아니라 소모되는 비용을 효과적으로 낮추게 한다는 많 은 연구결과들이 있다. 혈액 배양 양성인 환자 99 명을 대상으 로 시행한 조사에서 그람염색의 turnaround time (TAT)이 1 시간 미만인 경우와 1 시간 이상 된 경우를 비교했을 때 치명률 이 각각 $10.1 \%$ 와 $19.2 \%$ 로 유의한 차이가 보인다고 보고하였 다[1].

또한 미생물동정검사와 항생제 감수성 결과를 바로 보고했 던 290명의 환자군과 다음날 보고했던 284명의 환자군을 비교 평가한 연구에서 미생물검사결과의 보고시간이 빠를수록 환 자의 치료가 빨리 시작되며 이는 치료효과를 향상시켜 재원일 수를 감소시켰고 궁극적으로는 의료비용 감소로 이어졌다는 연구가 있으며[2], 야간에 결과를 보고하는 경우와 다음날 보 고하는 경우에 평균 TAT는 각각 39.2시간과 44.4시간이었고 입원기간은 10.7 일과 12.6 일이었으며 평균 병원비도 $\$ 4,927$ 와 $\$ 6,677$ 로 차이가 발생했다는 연구도 있다[3]. 이외에도 검사 시간 자체를 줄이기 위해 새로운 검사기술을 도입하거나 [4,5], 기존 검사에 다른 검사를 추가하여 최종 보고시간을 단축시키 는 방식을 사용함으로써 효율을 증가시킨 연구도 있다[6].

이러한 많은 장점을 확보하기 위해 신속한 검사와 보고체계 를 확립하는 일은 중요한데, 그 시작점이라 할 수 있는 국내 임 상미생물검사실의 야간, 주말 및 휴일의 운영형태에 대하여는 아직까지 정확한 현황 파악이 된 바가 없으며, 임상미생물검사 실의 운영에 대한 방향 제시와 검사실 질 관리 등의 측면에 대 해서도 연구된 바가 없다.

이에 국내 임상미생물검사실의 야간, 주말 및 휴일 운영현황 을 조사하고 분석하여 검사 및 업무형태에 대한 기본적인 제안 과 나아갈 방향을 제시하여 임상미생물검사실의 질 향상에 기 여하고자 한다.

\section{재료 및 방법}

2014년 4월 1일부터 11월 30일까지 대한임상검사정도관리 협회의 정도관리프로그램에 참가하는 341 개 기관을 대상으 로 임상미생물검사실의 검사의 수행, 검사실 운영에 대한 설 문을 시행하였다. 설문은 우편 및 e-mail을 통해서 발송하였으 며 회신은 우편 또는 온라인 설문조사 사이트를 통해 받았다 (Supplemental material 1).

\section{결과}

\section{1. 응답기관}

설문을 발송한 총 341 개 기관 중 조사에 응답한 기관은 128 개(37.5\%) 기관이었다. 응답기관의 규모는 900병상 이상 규 모의 종합병원이 22개(17.2\%), 600-900병상 규모의 종합병 원이 28개(21.9\%), 300-600병상 규모의 종합병원이 37개 (29.1\%), 300병상 미만 규모의 종합병원이 34개(27.7\%), 일 반 병원이 7 개 $(5.5 \%)$ 였다. 응답한 128 개 기관 중 7 개(5.5\%) 기관은 임상미생물검사를 시행하고 있지 않았으며 그 이유로 검사실 인원부족을 꼽았다.

\section{2. 평일 야간 근무형태 및 업무의 범위}

검사실의 평일 근무는 정규 근무시간인 주간 근무와 당직 근 무시간인 야간 근무 두 가지 형태로 운영되고 있었다. 야간 근 무의 형태를 살펴보면 통상 근무 후 전체 인원의 당직 근무형 태가 25개 기관(19.7\%), 통상 근무 후 일부 인원의 당직 근 무형태가 57개 기관(44.8\%), 통상 근무 및 3 교대 근무형태 가 11 개 기관 $(8.6 \%)$, 전담팀 근무형태가 2 개 기관 $(1.6 \%)$, 통 상 근무 및 야간 전담팀 근무형태가 27 개 기관(21.3\%)이었다 (Table 1).

응답한 기관 중 109 개 기관(88.0\%)에서 임상미생물검사의 검체를 접수하고 있었다. 접수부서로는 검체 접수실이 60개 기관(58.2\%)이 가장 많고 응급검사실이 38 개 기관(36.0\%), 임상미생물검사실이 7 개 기관 $(6.8 \%)$ 순으로 나타났다.

일반 임상미생물검사 부문에서 그람염색은 27 개 기관 (24.7\%)에서, 배지 접종은 45 개 기관(41.2\%)에서 시행한다 고 응답하였다. 미생물 동정 및 항균제 감수성 검사를 시행하

Table 1. Type of day and night shift work (total=127)

\begin{tabular}{lc}
\hline \multicolumn{1}{c}{ Working types } & No. (\%) \\
\hline $\begin{array}{l}\text { Regular working type } \\
\begin{array}{l}\text { Regular working types with on-duty, rotated for all } \\
\text { workers }\end{array}\end{array}$ & $25(19.7)$ \\
$\begin{array}{l}\text { Regular working types with on-duty, rotated for some } \\
\text { workers }\end{array}$ & $57(44.8)$ \\
$\begin{array}{l}\text { Three-shift workers } \\
\text { Regular working employees, separately run by a three- } \\
\text { shift work team }\end{array}$ & $11(8.6)$ \\
$\begin{array}{l}\text { Staff working night-shift only } \\
\text { Regular working employees with only one night-shift } \\
\text { team }\end{array}$ & $27(21.3)$ \\
Other & $5(3.9)$ \\
\hline
\end{tabular}


는 기관은 1 개 기관 $(0.9 \%)$ 이었다.

야간 근무의 경우 일부 인원의 당직 근무형태가 가장 많았으 며 대부분의 검체를 접수하였지만 접종 및 그람염색은 일부에 서만 진행되고 있었고 항생제 감수성 검사는 거의 이루어지지 않고 있었다.

병원 규모별로 분류해 보면 900병상 이상의 병원에서는 전 체 인원의 3 교대 근무방식이 22 개 기관 중 17 개 기관(77.3\%) 으로 가장 많았고, 600-900병상 규모의 병원의 경우도 전체 인 원의 3 교대 근무방식이 총 28 개 기관 중 17 개 기관 $60.7 \%$ )으 로 가장 많았다. 300-600병상 규모의 병원에서는 총 37개 기 관 중 통상 근무 후 전체 인원의 당직 근무형태와 통상 근무 후 일부 인원의 당직 근무형태가 각각 11 개 기관(29.7\%)로 동 일한 비율로 다수를 차지했고, 300 병상 미만의 병원의 경우 도 통상 근무 후 전체 인원의 당직 근무형태와 통상 근무 후 일 부 인원의 당직 근무형태가 전체 32 개 기관 중 각각 10 개 기관 (31.3\%)로 동일한 비율로 다수를 차지했다.

\section{3. 주말 근무형태 및 업무의 범위}

주말 근무의 경우 응답기관 중 12 개 기관(9.7\%)은 주말에 근무하지 않는다고 하였고 34 개 기관(27.6\%)은 토요일만 근 무하며, 일요일만 근무하는 기관은 없었다. 58 개 기관(47.1\%) 은 주말 모두 근무하나 업무가 토요일과 일요일이 달랐으며 19 개 기관(15.4\%)은 주말 모두 동일한 업무범위로 근무하였 다(Table 2).

토요일과 일요일 모두 같은 업무범위로 근무를 하는 기관 의 경우 모든 기관에서 검체 접수를 시행하고 있었다. 접수 부서로는 검체 접수실이 11 개 기관(55.0\%), 응급검사실이 3 개 기관(15.0\%), 임상미생물검사실이 7 개 기관(35.0\%)이었 다. 임상미생물검사 부문에서 그람염색 및 배지 접종은 16 개 기관(80.0\%)에서 시행하고 있었고, 배지 접종은 12 개 기관 $(60.0 \%)$, 동정 및 항생제 감수성 검사를 시행하는 기관은 10 개 기관 $(50.0 \%)$ 이었다.

토요일과 일요일의 업무범위가 다른 경우, 토요일은 84

Table 2. Type of weekend work (total=123)

\begin{tabular}{lc}
\hline \multicolumn{1}{c}{ Operated day } & No. $(\%)$ \\
\hline Non-operational on weekends & $12(9.7)$ \\
Only operational on Saturdays & $34(27.6)$ \\
$\begin{array}{l}\text { Only operational on Sundays } \\
\text { Operational on weekends with different scopes of } \\
\text { work between Saturdays and Sundays }\end{array}$ & $58(47.1)$ \\
$\begin{array}{l}\text { Operational on weekends with the same scope of } \\
\text { work on both Saturdays and Sundays }\end{array}$ & $19(15.4)$ \\
\hline
\end{tabular}

개 기관 $(91.3 \%)$ 에서, 일요일은 64 개 기관 $(58.7 \%)$ 에서 검 체 접수를 시행하고 있었다. 임상미생물검사 부문에서 그 람염색은 토요일은 75 개 기관(81.5\%), 일요일은 20 개 기관 (21.7\%)에서 시행하고 있었고, 배지 접종은 토요일은 72 개 기 관(78.2\%), 일요일은 38 개 기관(41.3\%)에서 시행하고 있었 으며 동정 및 항생제 감수성 검사의 경우 토요일은 71 개 기관 (77.1\%), 일요일은 9개 기관(9.7\%)에서 시행하고 있었다.

주말 근무의 경우 토요일은 $80 \%$ 에 가까운 기관이 근무를 하고 있으나 일요일은 $60 \%$ 정도의 기관만이 근무를 하고 있 었다. 또한 모든 기관에서 검체를 접수하고 있으나 일부 기관 만이 접종 및 그람염색을 시행하고 있었다. 항생제 감수성 검 사는 일요일에 비해 토요일에 시행되는 기관이 많았다.

병원 규모별로 분류해 보면 900병상 이상의 병원에서는 주 말 모두 근무하되 토요일과 일요일의 업무가 다른 형태의 운영 방식이 총 22 개 기관 중 15 개 기관(68.2\%)으로 가장 많았고, 600-900병상 규모의 병원에서는 주말 모두 근무하되 토요일 과 일요일의 업무가 다른 형태의 운영방식이 총 26 개 기관 중 12 개 기관(46.2\%)으로 가장 많았다. 300-600병상 규모의 병 원에서는 주말 모두 근무하되 토요일과 일요일의 업무가 다른 형태의 운영방식이 총 36 개 기관 중 21 개 기관 $(58.3 \%)$ 으로 가 장 많았다. 300 병상 미만의 병원의 경우는 토요일만 근무하는 운영방식이 총 31 개 기관 중 9 개 기관(29.0\%)으로 가장 많았 다.

\section{4. 휴일 근무형태 및 업무의 범위}

휴일의 경우 1 일만 쉬는 경우와 2 일 이상의 연휴의 경우로 나누어서 설문조사를 진행하였다(Tables 3,4$)$. 1일만 쉬는 경우 28 개 기관 $(22.7 \%)$ 에서 검체 접수만 진행한다고 응답하 였고, 17 개 기관 $(13.8 \%)$ 은 주말과 같은 방식으로, 5 개 기관 (4.0\%)에서는 주말 근무방식 중 토요일과 같은 방식으로, 23 개 기관(18.7\%)은 일요일과 같은 방식으로 운영한다고 응답 하였다. 2 일 이상 연휴인 경우, 37 개 기관(30.0\%)은 검체 접 수만 진행한다고 응답하였고, 13 개 기관(10.5\%)은 주말과 같

Table 3. Type of holiday work (1 day holidays) (total=123)

\begin{tabular}{lc}
\hline \multicolumn{1}{c}{ Scope of work } & No. (\%) \\
\hline Not operational on holidays & $48(39.0)$ \\
Only sample receptions conducted & $28(22.7)$ \\
Same operations as on weekends & $17(13.8)$ \\
Same operations as on Saturdays & $5(4.0)$ \\
Same operations as on Sundays & $23(18.7)$ \\
Other & $2(1.8)$ \\
\hline
\end{tabular}


Journal of LABORATORY MEDICINE and QUALITY ASSURANCE

Namsu Kim et al • Status of Working Conditions in Microbiology Laboratories

Table 4. Type of holiday work (for holidays longer than 2 days) (total=123)

\begin{tabular}{lc}
\hline \multicolumn{1}{c}{ Scope of work } & No. (\%) \\
\hline Non-operational & $5(4.0)$ \\
Only sample receptions conducted & $37(30.0)$ \\
Same operations as on weekends & $13(10.5)$ \\
Same operations as on Saturdays & $7(5.6)$ \\
Same operations as on Sundays & $16(13.0)$ \\
Selective operations & $36(29.2)$ \\
Other & $9(7.3)$ \\
\hline
\end{tabular}

은 방식으로, 7 개 기관 $(5.6 \%)$ 에서는 주말 근무방식 중 토요일 과 같은 방식으로, 16 개 기관(13.0\%)은 일요일과 같은 방식으 로 운영한다고 응답하였다. 그리고 36 개 기관( $29.2 \%)$ 에서는 선택적인 날짜에만 임상미생물검사실을 운영한다고 응답하였 다.

병원 규모별로 분류해 보면 900병상 이상의 병원에서는 하 루만 쉬는 경우, 일요일과 같은 방식의 근무형태가 총 22 개 기관 중 7 개 기관(31.8\%)으로 가장 많았고, 이틀 이상 휴일 일 경우 선택적인 날짜에만 검사실을 운영하는 방식이 8개 기 관(36.4\%)으로 다수를 차지했다. 600-900병상 규모의 병원 에서는 하루만 쉬는 경우, 업무범위가 같은 주말 운영방식으 로 운영하는 경우와 검체 접수만 진행하는 병원이 총 26 개 기 관 중 각각 5 개 기관 $(19.2 \%)$ 으로 가장 많았고 이틀 이상 휴일 일 경우 선택적인 날짜에만 검사실을 운영하는 방식이 7개 기 관(26.9\%)으로 다수를 차지했다. 300-600병상 규모의 병원에 서는 하루만 쉬는 경우, 일요일만 근무하는 방식이 총 36 개 기 관 중 11 개 기관(30.6\%)로 가장 많았고, 이틀 이상 휴일일 경 우 선택적인 날짜에만 검사실을 운영하는 방식이 12 개 기관 (33.3\%)으로 가장 많았다. 300병상 미만의 병원에서는 하루 만 쉬는 경우나 이틀 이상 쉬는 경우 모두 검체 접수만 진행하 는 형태가 총 31 개 기관 중 각각 10 개 기관 $(10.0 \%), 17$ 개 기 관 $(54.8 \%)$ 으로 가장 많았다.

\section{Cerebrospinal fluid 검체의 검사 진행}

빠른 처리가 필수적인 뇌척수액(cerebrospinal fluid, $\mathrm{CSF}$ ) 검체의 경우, 야간 근무하는 109 개 기관 중 96 개 기관 (88.0\%), 동일한 업무범위로 근무하는 주말의 경우 20개 기 관 중 19 개 기관(95.0\%), 업무범위가 다른 주말의 경우 92개 기관 중 87 개 기관 $(94.5 \%)$ 등 대부분의 기관이 접수를 진행 하고 있었으나 그람염색은 야간 근무하는 109 개 기관 중 23 개 기관(21.1\%), 동일한 업무범위로 근무하는 주말의 경우 20개
기관 중 7 개 기관(35.0\%), 업무범위가 다른 주말의 경우 92 개 기관 중 40 개 기관 $(43.4 \%)$ 만이 그람염색을 시행하였다. 검 체 접종도 야간 근무 109 개 기관 중 40 개 기관( $36.7 \%$ ), 동일 한 업무범위로 근무하는 주말의 경우 20 개 기관 중 15 개 기관 (75.0\%), 업무범위가 다른 주말의 경우 92 개 기관 중 66 개 기 관(71.7\%)만이 접종을 시행하였다.

\section{고찰}

본 연구를 통해 국내 임상미생물검사실의 야간, 주말 및 휴 일의 검사실 운영형태는 정규 근무시간과는 달리 제한적으로 이루어지고 있었으며 다양한 형태를 취하고 있음을 알 수 있었 다.

이는 각 병원마다 발생하는 업무량의 차이와 추가 근무에 따 라 발생하는 인건비 등의 비용적인 부분이 수익과 맞지 않는 등 여러 가지 여건이 병원마다 다양하기 때문일 것으로 추정된 다. 특히 인건비 항목의 경우 검사실에 근무할 수 있는 총 인원 수나 교대 근무 및 초과 근무에 투입할 수 있는 인원수에 직접 적인 제한요인이 될 수 있는 부분으로 생각된다.

검체 접수의 경우 대부분의 병원에서 바코드를 이용한 접수 방식을 채택하고 있기 때문에 적은 인원으로도 충분이 업무량 을 감당해 낼 수 있어 야간이나 주말, 휴일 등 모든 근무환경에 서 대부분 시행되고 있다. 하지만 실제로 검체의 접종이나 그 람염색 등은 접수와는 달리 수기로 진행되는 부분이 상당 부분 을 차지하는 검사의 특성상 충분한 근무인력을 보장받지 못하 는 병원은 검사 진행에 어려움을 겪을 수밖에 없으며 검사가 복잡할수록 이러한 경향은 더욱 심화될 것으로 생각해 볼 수 있다. 동정이나 항생제 감수성 검사의 경우는 전문의 인력까지 필요한 경우이기에 시행하는 병원보다 그렇지 못한 경우가 더 많은 것을 알 수 있다.

이러한 문제는 궁극적으로 검사에 따른 수가 산정이 지나치 게 낮게 책정되어 있기 때문인 것으로 보인다. 앞서 언급한 것 처럼 수기로 진행되는 검사 부분이 많은 것과 더불어 추가적으 로 소모되는 검사시약이나 배지 등도 그 수량을 예측하기 힘든 경우가 많다는 점 또한 현재 책정되어 있는 수가가 현실적이지 않은 이유이기도 하다. 따라서 검사실의 운영에 필요한 충분한 비용의 확보가 불가능한 상황을 만들게 되고 빠른 검사와 결과 의 신속한 보고에 대한 수많은 장점에도 불구하고 시행되기 어 렵게 만드는 요인이다.

$\mathrm{CSF}$ 검체의 경우 접수를 시행하는 기관 비율과 검사를 진 행하는 기관 비율 간에 차이가 있는데, 이는 검체가 접수는 되지만 이후 검사가 진행되지 않는 경우가 있음을 의미한다. 
$\mathrm{CSF}$ 검체는 통상적으로 채취 후 24 시간 이내에 검사를 진행 해야 함에도 불구하고 적절한 시간 내에 진행되지 못하게 되면 검사의 적절한 질이 보증되지 않기에 문제가 될 수 있는 부분 이며 반드시 개선이 필요하다.

문제의 해결을 위해 수가 개선 등을 통한 비용의 확보가 가 장 이상적인 방법이지만 인적 자원의 관리 또한 필요한 부분 이다. 인적 자원 개념에서 볼 때 인적 자원의 관리란 검사자 수 를 늘리는 양적인 개념뿐만 아니라 검사자 개개인의 검사에 대 한 질적인 관리를 포함한다. 미생물검사가 가능한 인력을 늘리 는 방법이 우선적으로 불가능할 경우 기존에 임상화학이나 혈 액검사 분야의 업무를 담당하는 검사자의 경우도 교대 근무상 황에서는 한정적으로 검체의 접수나 부적합 검체를 분류하는 등의 비교적 간단한 업무에 도움을 받을 수 있도록 하는 것도 방법 중에 하나가 될 것이다. 이러한 인적 자원관리를 위해서 는 업무흐름을 단계별, 수준별로 구분하여 지침을 만들어 적용 하는 것이 필요하다[7]. 이는 각 단계마다 어느 정도의 수준의 인력이, 어느 정도 인원이 필요한지 검사 업무흐름을 기본 골 격으로 적절하게 구분하여 파악하고 세밀하게 조정하여 업무 량을 분산시키는 것을 가능하게 할 수 있다.

이러한 방법을 통해서 상당수의 기관이 앞서 언급한 문제들 로 인해 접종 및 그람염색 등의 미생물검사를 야간 및 주말 또 는 휴일에 시행하고 있지 않고 세균 동정 및 항생제 감수성 보 고도 잘 이루어지지 않는 이 상황은 분명히 개선이 가능하다고 생각된다.

일례로 일본에서는 성공적으로 연중무휴제 방식으로 미생물 검사실을 운영하여 그 결과를 보고하였던 연구가 있다. 연중무 휴제 방식으로 임상미생물검사실의 운영방식을 변경한 이유 는 의료제도에서 포괄청구제도로의 변화, 원내 감염증으로 인 한 환자의 후유증에 대한 배상 판결 때문이었다.

포괄청구제도로 수가체계가 변경된 상황에서는 감염증 으로 인해 입원기간이 장기화할수록 추가적인 비용이 병원 의 손실이 되므로 감염을 단시간 내에 인지하고, 대응하여야 하는 시스템으로 전환할 필요가 있었고, 제왕절개수술을 받 은 임산부가 메치실린 내성 포도알균(Methicillin-resistant Staphylococcus aureus)에 의한 원내 감염이 있었으나 검사 및 보고가 제때 이루어지지 않아 중증의 후유장애를 입은 사건 이 발생함으로써 연중무휴제 운영방식을 확립하여 검체 접수 와 결과보고가 매일 가능하게 한 계기가 되었다. 연중무휴제를 도입한 후에 후 혈액 배양 양성 검체의 최종보고까지의 시간이 최대 1.4 일이 단축되었으며 혈액 배양 양성 시 균 검출결과의 중간보고에 따른 항균제의 신속한 투여가 사망률 감소의 유의 한 영향을 미쳤다[8].
국내에서도 중동호흡기증후군(Middle East respiratory syndrome) 유행 이후로 감염관리의 중요성이 부각되고 있으 며 임상미생물검사실은 가장 중요한 근거를 제시해주는 부서 이다. 따라서 일본의 사례와 같은 연중무휴제 운영방식의 도입 에 충분한 당위성을 부여할 수 있다고 생각된다.

궁극적으로 임상미생물검사실이 연중무휴제 방식으로 전환 된다면 환자와 병원 모두에게 이익이 될 수 있을 것이지만 한 번에 달성하는 것은 매우 어렵기 때문에 점진적 도입을 검토해 야 할 것이다. 일본의 사례와 같이 점진적 도입과 세밀한 준비 가 필요한데, 예를 들어 임상미생물검사 중 임상에서 치료방침 을 선택하는 데 많은 도움을 줄 수 있는 검사를 우선적으로 선 별하여 순위화한 후 먼저 적용하는 방안도 취할 수 있는 좋은 전략이라 생각된다. 특히 그람염색의 경우 비교적 간단한 검사 이며 염색 부분에서 자동화가 되어 있어, 광범위 항생제 선택 에 큰 도움을 줄 수 있으므로 먼저 적용한다면 큰 효과를 볼 수 있을 것이다.

외국에서도 임상미생물검사실의 주 7일 24시간 운영에 대한 고민이 시작되고 이에 대한 문헌이 보고되고 있다 $[9,10]$. 다제 내성균의 증가와 이에 따른 감염관리, 광범위 항생제 사용과 면역이 억제된 환자의 증가 등의 변화하는 의료환경에 대응하 기 위해 우리나라의 임상미생물검사실도 발맞추어 적절한 대 응을 모색해야 할 시점으로 생각된다.

\section{감사의 글}

본 연구는 대한임상검사정도관리협회의 2014년 학술연구비 (2014-05)에서 지원받아 이루어진 연구이다.

\section{SUPPLEMENTARY MATERIALS}

Supplementary materials can be found via https://doi. org/10.15263/jlmqa.2019.41.2.111.

\section{REFERENCES}

1. Barenfanger J, Graham DR, Kolluri L, Sangwan G, Lawhorn J, Drake CA, et al. Decreased mortality associated with prompt Gram staining of blood cultures. Am J Clin Pathol 2008;130:870-6.

2. Galar A, Leiva J, Espinosa M, Guillen-Grima F, Hernaez S, Yuste JR. Clinical and economic evaluation of the impact of rapid microbiological diagnostic testing. J Infect 
2012;65:302-9.

3. Barenfanger J, Drake C, Kacich G. Clinical and financial benefits of rapid bacterial identification and antimicrobial susceptibility testing. J Clin Microbiol 1999;37:14158.

4. Doern GV, Vautour R, Gaudet M, Levy B. Clinical impact of rapid in vitro susceptibility testing and bacterial identification. J Clin Microbiol 1994;32:1757-62.

5. Oosterheert JJ, van Loon AM, Schuurman R, Hoepelman AI, Hak E, Thijsen S, et al. Impact of rapid detection of viral and atypical bacterial pathogens by real-time polymerase chain reaction for patients with lower respiratory tract infection. Clin Infect Dis 2005;41:1438-44.

6. Barenfanger J, Drake C, Leon N, Mueller T, Troutt T. Clinical and financial benefits of rapid detection of re- spiratory viruses: an outcomes study. J Clin Microbiol 2000;38:2824-8.

7. Miller JM. Cost-saving strategies for diagnostic microbiology laboratories. Clin Microbiol Newsl 2013;35:195204.

8. Komori T, Fujita N, Hirose Y, Kimura T, Kyotani N, Kurahashi S, et al. Establishment of a microbiology laboratory open 365 days a year and its impact. Rinsho Byori 2009;57:1186-91.

9. Blondeau JM, Idelevich EA. The 24-h clinical microbiology service is essential for patient management. Future Microbiol 2018;13:1625-8.

10. Dauwalder O, Vandenesch F. Clinical microbiology laboratory: from the Pasteur model to the 24/7 clinical chemistry concept. Clin Microbiol Infect 2014;20:O593-4. 